\title{
The Symbolized Countryfolks in Shen Congwen's The Border Town
}

\author{
Liang Ying \\ Beijing Foreign Studies University, Beijing, China
}

\begin{abstract}
Shen Congwen is one of China's most renowned modern writers. The Border Town portrays the people and customs of a corner of Shangri-la, and humanizes, if not romanticizes nature and the country folk who are living in. The Border Town is perfect not only in subject, but in style and form as well. The complex theme of the novel is depicted through the methods of symbolism and contrast. The current study focuses on how Shen made use of symbolism to portray the country folk. Although Shen used various kinds of symbolisms, natural, sexual, religious, celestial, and political, only the first two kinds will be dealt with in this paper. Symbols discussed in the paper include Cui Cui, Grandpa, the Border Town, river, water, ferry, bamboo, dreams, pagoda, animals, flowers, dreams, colors, etc.
\end{abstract}

Keywords: symbol, country folk, nature, simplicity, vitality

Shen Congwen (1902-1988) is one of China's most renowned modern writers. "His best works portrays the conditions and social customs of the minority nationality region in the border of Hunan and Guizhou" (Tang, p. 362). The Border Town (1934) is such a work. It vividly describes the landscape of the remote border town and the customs of the local people. In his foreword to The Border Town, the author says:

I will not stop here. I will give them an opportunity to compare. In another time, I will touch on the 20 years of civil war and on what the peasants have become after losing their virtues of simplicity, thrift, peace and honesty, brought on by the pressures and impact of the war. (qtd in Wah, p. 78)

He is talking about the growing contrast between the two backgrounds, or two phases of life: (1) time of natural simplicity and happiness; (2) the gradual erosion of virtue and disappearance of the ideal, brought on by the impact of modern civilization and commerce. While the novel does explore the isolation of human souls, it is more basically a pastoral tale of rural virtues in remote west Hunan.

Some critics praise Shen only as a "stylist". Although how much weight we can give to this statement deserves debate, it is true that The Border Town is perfect not only in subject, but in style and form as well. The complex theme of the novel is depicted through the methods of symbolism and contrast. As it is beyond the scope of the paper to investigate how in this novel Shen used style and form as a whole to address his thesis, the current study is going to focus on how Shen made use of symbolism to achieve his purpose, as he made profuse use of symbolism in the book. Again, although Shen used various kinds of symbolisms, natural, sexual,

Liang Ying, Ph.D., Associated Professor, Graduate School of Translation and Interpretation, Beijing Foreign Studies University.

Correspondence concerning this article should be addressed to Graduate School of Translation and Interpretation, Beijing Foreign Studies University, Beijing, 100089, China. E-mail: yingliang26@163.com. 
religious, celestial, and political, only the first two kinds will be dealt with in this paper, not only because I have an overwhelming urge to delve into these two, but also because they tie in perfectly and tidily with the novel's topic under discussion.

\section{Simplicity}

The Border Town reminds the readers a prototype of a Shangri-la. The background of the novel is confined to a corner of the river outside Chatong - the River Street and the Blue Stream Valley. The Border Town in this sense symbolizes a corner of the Shangri-la where modern civilization has not made any inroads and decadence is not widespread. In fact, Shen has made the scenario similar to that of "The Shangri-la” by Tao Yuanming:

This river, famed in history as the You, is now known as the White River. After reaching Chenzhou where it mingles with the River Yuan, its waters grow turgid. But if you sail upstream, you can see clear to the bottom of pools thirty to fifty feet deep, so transparent is the water. In sunlight, even the white pebbles on the river bed and the veins on the cornelian pebbles stand out distinctly. The fish darting to and fro seem floating in air. (p. 10)

The description of the river alone is powerfully expressive. The river banks are the source of human culture. In The Border Town, the houses are half on land and half over water. When calm, the water is crystal clear but when flooded, we see animals and ships drifting in the strong current. This is the rhythm of nature and the people act in compliance with it. Water is a source of happiness to the residents of The Border Town, associated with joyous occasions such as the dragon boat race and duck-catching in the river.

Cui Cui (the pubescent heroine) is naturally a daughter of nature. Every time she goes to town, her heart thumps with fear. She feels happy only when she returns to the countryside. We find that she has more than once used the bamboo grove as a refuge. As a young child, she would always escape to the woods whenever she encounters a stranger. As a grown up, she also adopts this attitude when someone comes to match-make. When Shun Shun sends a match-maker to her house, she pretends to chase chickens and runs to the white pagoda behind the house. She does the same when Nuo Song passes by and calls for the ferry. Recognizing that he is the person she likes, she is "surprised and like a small animal, she turns tail and runs towards the bamboo grove".

A couple of symbols can be drawn from this analysis. First, the bamboo grove is a symbol of her world of purity or the bamboos are the embodiment of Cui Cui. Cui Cui is projected by images of the Bamboo Raft, Bamboo Grove and the Woods. Also, after the death of her grandfather, the people arrange for Cui Cui to take over the job of plying the ferry. This is implied in the following paragraph:

Soon every body around Chatong knows of it. The wharf-master sends for an empty boat to take a plain wood coffin to Green Stream. Yang and another old soldier hurry to the hills by the stream to cut a few dozen big bamboos and lash them together as a make-shift ferry. When this raft is ready, they punt it across and Yang, leaving the old soldier in charge of the ferry, goes up to see his dear friend. (pp. 94-95)

The "make-shift ferry" is a symbol of Cui Cui as it is made of bamboo. Therefore the use of bamboo for the raft signifies the employment of Cui Cui as a ferry girl. In chapter 12, Old Tien Bao is thinking of marrying Cui Cui. He said, “I've a good mind to buy both those hills by Green Stream and plant bamboos all round to make a small kingdom of my own” (pp. 63-64). Those who do not know naturally symbolism will not catch its meaning. Cui Cui is the bamboo, the ferry.

Moreover, it reveals in Shen's world, the country folk are interestingly attached to their animals: Cui Cui's 
attachment is to her dog. The yellow dog is an important character in the book. Its depiction is very vivid. Other examples in Shen's works include Hui Ming (of "Hui Ming”) and Old Mrs. Wang (of “A Country Town”) to their respective chickens, the protagonist of "Ox" to his draft animal.

The country folk live a simple life and have simple habits. In the novel, symbols such as the countryman's pipe which represents simplicity is set in opposition to city man's cigarette (appeared in various Shen's works that depict urban life).

This does not say that country folks have no social life. The community cares for one another as individuals. The folk's community spirit is represented in the novel as they chip in to repair flood damage, rebuild the pagoda behind Cui Cui's home, and so forth.

Moreover, the great outdoors, all the greater at the frontier, "socializes” the country folk, sometimes in lieu of society. Cui Cui's nature is located in using the logic of a classical Chinese poem:

Wind and sun have tanned the growing girls' skin, her eyes resting on green hills are as clear as crystal. Nature is her mother and teacher, making her innocent, lively and untamed as some small wild creature. She has the gentleness of a fawn and seems not to know the meaning of cruelty, anxiety or anger. Should a stranger on the ferry stare at her, she fixes her brilliant eyes on him as if ready to fly any instant to the mountains; but once she knows no harm is meant, she finishes her task calmly. (p. 7)

Cui Cui is typical of Shen's heroines: dark, like Yao Yapo (of Long River), San San (of "San San”), and in real life, Zhang Zhaohe, Shen's bride. Their beauty runs counter to the Chinese ideal.

Yet, the sociability of Shen's country folk as such may appear to be debatable. Cui Cui has undeveloped social skills; she is immature, just on the brink of her young womanhood. Shen enjoys probing generational misunderstandings and communications gaps, even impasses, as between Cui Cui and her grandfather. The Border Town as a whole explores the isolation of human souls. Shen Congwen's most famous definition of the country person occurs in his 1936 "Prefaces to My Exercises", wherein he defiantly proclaims that,

A country fellow is by nature an inveterate country bumpkin. What he likes or dislikes, and what brings him sorrow, or happiness, is distinctly up to him, quite at odds with the tastes of a city person! He's conservative, and stubborn; he loves the soil; he's no pushover, but trickiness is beyond him. He takes everything to heart, almost too much to heart, which in some instances may make him out to be a "simpleton". (qtd in Kinkley, p. 159) ${ }^{1}$

Being simple does not mean just unskilled, poor and blank, his country folks are "comfortably supplied with the simple necessities of food and clothing” (Kinkley, p. 161). Though country people may be seen eating a poor man's diet of sweet potatoes, or gathering bracken (a fern, mostly consumed in time of famine), the very poorest do not dwell on their poverty. In fact, his most memorable country-folk characters are usually not the poorer ones. Simple country folks are awarded by the riches of the soil or the waters: grains, fruits, eggs and fishes. These riches result from the folk's own labor and loving upkeep. They are not cashed in for silver, fine clothes, or opium. Cui Cui does not even hanker after the finer things of life, but fears them. Country folk value things more than money.

Mao Zedong restated peasant liabilities as virtues, but instead of seeing country people as leading dignified and stable lives on their own terms, he praised them for quite the opposite characteristic: a revolutionary malleability predicated on precisely the view Shen wanted to contradict. (Kinkley, p. 160)

\footnotetext{
${ }^{1}$ Originally “Xizuo xuanji daixu” $<<习$ 作选集代序 $>>$ (In Lieu of a Preface for my Selected Exercises) p. 120. Jeffrey C. Kinkley trans.
} 


\section{Health and Vitality}

Shen inverted the traditional prejudice against the country folk, turning their social liabilities into moral virtues such as health, individual dignity, self-determination, and vitality.

In Shen's works, city folks are romantic, and they need nature to heal them, because their psychic development leads in "unhealthy" directions. Yet nature gives to country folks—life, rest, vigor, as well as that play of the senses that city folk lack. Above all nature creates a positive, vigorous resiliency in the people who adapt to it.

Country folk's adaptation draws on an inborn vitality inherent in life, which develops through struggle with exterior, often natural, forces. Harmony with nature is not easy. It requires discipline. Shen often speaks of country folk challenging the elements, like boatmen going against the Yuan River rapids. Relations in families are always based on love and mutual caring; the family is often disrupted by death, so each member is precious. Yet, fathers encourage their sons to go out into the wilds and face the rapids, to make men of themselves. They grant their young folk independence, leaving their survival up to fate, as of the case in The Border Town. Even the river town folk of this novel have many opportunities for heroics, as during floods, when they risk all to save the lives and property of others.

Yet premonitions of death fill the country people's dreams, as ruination in the rapids fills the songs of the boatmen. It is during a flood that Cui Cui's grandfather, her guardian, quietly passes away. As said earlier, water is a source of happiness to the residents of The Border Town, but it is also a source of sorrow, symbolized by the drowning of the elder brother, Tian Bao when his boat capsized.

Shen also pens romantic accounts of West Hunanese banditry and glorifies the open, honorable fighting in his region. And Tian Bao, is good at defending himself. Shen's acceptance of this much of the martial ethic may explain why he felt, even in the 1940s, that the hope of his region lay with its brave and idealistic young military officers. Shen loved ideals and then realm of myth. It was with fanciful stories of Miao singing masters, star-crossed lovers, and fighting brothers that he most explicitly delineated the regional myth he depicted so beautifully in the novel.

A great contradiction between tribal vigor and Confucian decadence is running through most of Shen's works. Sex is one of the most prominent symbols of folk vigor. "Sex is rendered mysterious and wonderful in most of Shen's tales about adolescent country girls” (Kinkley, p. 181), like “After Rain”, "The Lovers”; "down-to-earth and essential to vitality in tales about rougher folk" (Kinkley, p. 181), like the title hero of "Baizi”, a boatman.

Shen's female adolescent "innocents" are highly sexed, too, with swelling bosoms and so forth. In the novel, they are allowed some initiative in mating, though this is unusual in ordinary Han society (less so among the Miao). Shen fills Cui Cui's world with images of erotic love songs, bridal processions, and phalli, from flutes to racing dragon boats. Autumn is the season not just of harvest, but of marriage. Cui Cui's emotional maturation is related year by year, against the clock of Dragon Boat Festivals. The festival evokes association of Chu regionalism, the striving of men against the elements and each other (in the boat races), and the riverine, watery symbols that Shen uses to delineate Cui Cui's erotic awakening instead of the historical associations of Qu Yuan. Fishes are symbols of her sexual maturation and losing her sexual innocence as well.

In the novel, Cui Cui has subliminal premonitions of impending loss of her innocence. Shen fills Cui Cui's world with images of being "eaten by the big fish" (losing her sexual innocence). There is sexual symbolism in 
her daydreams: "She had no idea how large Dong Ting Lake might be, nor had she ever seen one of those large boats [of which she dreamed]. What was even stranger, she herself didn't know why she had come to think of these things", "She begins to realize, and fear, her blossoming sexuality", "she thought of many things. Of stories of tigers eating people, of the four-line mountain songs used by people to curse each other, of the square pit in a paper-making factory, of the molten iron being let out of the smelting furnace of an iron works. She seemed to want to go over everything she had heard and seen”.

Even the act of love is rendered innocent. In the novel (also in "Baizi”, "The Husband”), Shen Congwen is intent on pointing out that even the sale of sex (an economic necessity to those in the trade) does not inhibit country folk from forming long-term attachments to lovers. Prostitutes enjoy both the thrill of sex and the true love of fully human relationships with their steady boyfriends, even as they earn their living from the merchants.

What particularly caught readers' attention was Shen's extension of country virtues to boatmen, prostitutes, soldiers, and others apt to be considered drifters. If the old gentry were more sympathetic than modern urbanities toward people who were rooted in the soil, they were quite intolerant of people lacking a fixed abode and known origins. Modern city dwellers, meanwhile, were acquiring new, Western viewpoints with which to despise those who sold their bodies. Shen had more liberal views on sex, and a respect for people who lived beyond the comforts of society and risked their very lives. Popular writers had blazed this trail before, but the seriousness with which Shen made his point was still startling in his time.

\section{The Death, the Pagoda}

Shen acknowledges that The Border Town basically creates a pattern of life that is beautiful, healthy, natural, and not contrary to human nature, that is, one selectively remembered and deliberately rendered idyllic. But he also gives another advice that readers are not supposed to limit themselves to the confines of its "freshness" and "simplicity". We must explore the significance behind the story. In fact the novel does not present us all an ideal state of nature. Hopes and fears are mixed all through.

The country folk are no strangers to human misunderstandings and tragic feuding, which intrude in this idyllic world. It is more the isolation of youth than of nature that Cui Cui is kept from knowing distress and melancholy. As she matures, the more complicated emotions begin to unfold. She becomes wary of her sexual feelings, and sensible of death, which are exemplified in her dreams and fantasies.

Though country folk take pleasure and pride in their daily routines, they also take pleasure in their dreams. Cui Cui, who searches for shapes in the clouds, lives within her dreams and fantasies. The dreams present Shen's vision of the country folk's own interior world, one closer to the basics of elemental vitality, and having subliminal Freudian meaning. Yet country folk are not fully conscious of their own feelings, and unable to put outsiders' social behavior into recognizable categories.

Freudianism flavors the novel and Wah argues that "the novel explores the psychological development of its pubescent heroine, Cui Cui, against the background of the aging and gradual decline of her grandfather, the village ferryman” (p. 76). Thoughts of death, and the need to arrange for Cui Cui’s well-being, do preoccupy Grand father. Meanwhile Cui Cui, too, has subliminal premonitions of impending loss of Grandpa.

I find it hard put to agree that Grandpa is a figure representing decline and rigidity. But he is a lonely fisherman at least. A few simple strokes in the novel form the lonely fisherman fishing in the middle of the river in the painting "Fishing Alone in the Cold River", and the Taoist under the pine tree in the painting 
"Listening to the Soughing of the Wind under the Pine Tree". They are mere dots, nameless and are not personalities from any classical work. However, their significance is profound and Grandpa is such a character. Grandpa is 70 years old. Having been in the ferry service for 50 years, he is coming to the end of his life. The author makes frequent use of words such as "sleeping" and "tired" to indicate his condition. The feeling of "tired" is shown in the first chapter: "Tired out, he lies down to sleep on a rock near by; and if someone hails them from the further shore, Cui Cui will not let her Grandfather get up but jumps aboard to take his place as nimbly as you could wish” (pp. 7-8).

It is clear that Cui Cui would be his successor. Now let's take a look at the dialogue between them in chapter 6:

I am big enough to stay and mind the boat.

An old fellow like me ought to mind it.

An old fellow like you ought to rest. (p. 33)

The words "tired" and "rest" have the same meaning here. In chapter 10, Cui Cui says that her grandfather has a sunstroke and asks him to take a rest under the shade. Later the old boatman goes home and lies on the bed. Finally, Grandpa dies of illness in a stormy night. Cui Cui is unaware and thinks that her grandfather is still sleeping:

"When she wakes, it is light and the rain has stopped, but runlets are racing down the hills into the stream. Her grandfather still seems fast asleep” (p. 93). Being naïve, Cui Cui is ignorant of the horror of death. She does not know what death is and still thinks that her Grandfather is asleep.

Grandpa is strong-willed. He does not admit he is old and refuses to take a rest. Shen Congwen skillfully portrays this character by showing that prior to his death he was still weaving sandals. In chapter 19, the old boatman feels unwell. He felt exhausted now. Asking Cui Cui to look after the boat, he returned to the house and "fell asleep". Later, Cui Cui feels uneasy and runs home to see how her grandfather is. "She thought he had gone to bed long ago, but she found him sitting on the threshold and weaving sandals." "Oh, Grandfather, how many pairs of sandals do you want? There are already 14 pairs hanging over your bed? Why don't you rest now that you are ill?" Cui Cui said.

Grandpa is anonymous; he is just called Grandpa. He is a character who merges with nature. (Cui Cui was also originally without a name. She was later called Cui Cui because "their home was among bamboos ad hills of a glorious emerald green, the old boatman gave the poor mite the name”) (p. 7). For 50 years, Grandpa never left the boat for a day. He is the boat and the boat is he. As such, when he dies, the boat is washed away by the water. Cui Cui first notices the disappearance of the boat before she discovers the death of her grandfather:

The cliff has not caved in after all. But as she looks this way and that for the boat, a gasp escapes her-the white pagoda behind their hut has gone! She races back there. Yes, the pagoda has crumbled into a mountainous clutter of rubble and bricks. She screams in terror for her grandfather. When he makes no answer, she dashes inside to shake him frantically. Still he utters not a sound. His life has guttered out as the storm died down. (p. 94)

Wah creatively establishes the link between the white pagoda and Grandpa. "The white pagoda is the embodiment of Grandpa” (Wah, p. 76). It is said that the white pagoda was erected to preserve the bones of Sakyamuni. Later, it became a symbol of worship, a geomantic stabilizer and a monument. Grandpa's family is the only family living below the pagoda. He is the last symbol which represents simplicity, thrift, peace and happiness. That is why the people wanted to donate to re-erect the pagoda. It is an expression that human 
kindness is not dead. The storm, the washing away of the boat and the collapse of the white pagoda during Grandpa's death is an evocative portrayal of the harmonious coexistence between man and nature.

The color white bears a very evident relationship to death in Shen's works. For instance, in "San San", the namesake heroine remembers her deceased father, the miller, as a man always covered in white dust, the ashen-completed stranger as one with a camellia-colored face, his nurse as the one in the white cap. Later the body of Grandpa is also buried under the pagoda. This is to say that the simplicity, peace and happiness of the Shangri-la is also interred here. When we see a pagoda, we think of it as a place where the bones of Buddha are stored and is, therefore, a place of worship. So too, when the people of Chatong see the white pagoda, they will recall the disappearing Shangri-la and the good that has been interred under it. It represents the disappearance and reconstruction of local rural virtue.

Shen points up the ways in which his country folk, especially in a family setting, are able to communicate their moods and feelings without much recourse to speech. But when Shen depicts the plain folk in their communities, especially in family situations, their world comes alive. Indeed, Cui Cui goes through a stage of hostility toward her own grandfather, before finally accepting her new role as the one responsible not only for herself but for him. Finally, love songs she hears while sleeping lift her subconscious mind up to pick erotically red saxifrage. These wildflowers represent love and its hidden dangers. Cui Cui absentmindedly gathers some, in combination with whip-shaped bamboo shoots. When a flood carries away the landing and marks the death of Granddad, Cui Cui is torn loose from her mooring, ready to face an indefinite future of love and ever-present death.

“A major weakness in Shen's portraits of rural characters may well be that between his careful treatment of rural community and custom on the one hand, and his extraordinary delineation of rural interior lives on the other" (Kinkley, p. 160). For instance, the folk’s community spirit is represented once in the novel as they chip in to repair flood damage, rebuild the pagoda behind Cui Cui’s home; but Cui Cui between dreams building miniature dams and pick flowers is treated lavishly. Shen is criticized for letting the exterior personality traits of his characters fall into stereotypes: strong, outspoken martial "brothers" (like Tian Bao of The Border Town), and beautiful, intelligent, and imaginative Miao bards (like Nuo Song of the novel), dreamy adolescent girls (like Cui Cui of the novel) and earthy old men (like Grandpa of the novel); and so forth.

The Border Town portrays the people and customs of a corner of Shangri-la, and humanizes, if not romanticizes nature and the country folk who are living in. But underlying theme is still complex, the "shift from spiritualism to materialism and the conflict between soul and desire” (Wah, p. 80) between the phases of life is not so evident. The second phase, which is very significant to the novel, can also be called the predicament of the last piece of Shangri-la. Yet due to the limit of the scope, the third section of the paper only focuses on Grandpa's death.

\section{Parable of the Whole Chinese People}

For his collection of short stories A Jin published in 1943-the tenth year since he started creative writing — Shen Congwen wrote a foreword called "The Exercise" in which he said: "My intention is to build a small Greek temple of hard rocks atop a mountain. My ideal structure should be exquisite, compact and symmetrical, small but not dainty. The God of worship is 'humanity'” (qtd in Wah, p. 67). This may be regarded as the key to Shen's sense of the value of his works. His intention to set a place for human nature in his works shows his concern for the basic question of the survival of mankind and his affirmation of the 
spiritual value of mankind.

If we cast our eyes on a higher plane, Shen's works about the West Hunanese have a broader symbolic meaning even in the realm of history. They may be read as parables about the whole Chinese people, who by the 1920's had grown dispirited in the world. Shen was eager to use his social and historical vision to find grounds for hope for Chinese to get a national renewal. That explains why he sometimes writes sentimentally and with regional bias about frontier areas (The Border Town is said by many critics to be an example). He is always searching for hope from among a hypothetical "innocent” social group within China. Yet he also writes out of informed social concern for the plight of China's hinterlands.

A big thinking I had when I undertook this study is the hidden significance of symbolism is hard to grasp because the experience may be common though the meaning it represents is not fixed. The American poet, Robert Frost, uses symbolism profusely to attract a large number of readers. The last stanza of his poem "Stopping by Woods on a Snowing Evening” reads:

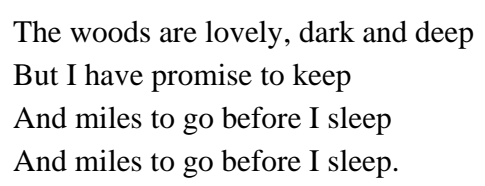

Taken literally, this may be the experience and feeling of a tourist but in the language of symbolism, "the woods in a winter evening" implies old age and the word "sleep" implies death. The image of this type of symbolism is sometimes formed by the natural phenomenon of the cosmos, sometimes by the experience of the character in the fiction and sometimes by other things. Whether interpretation correlates with the writer's intention relies on our common experience. This also links to another concern that I have: If we could conduct anthropological or mythological research first, and on its bases, link these symbols above-mentioned, such as river, water, ferry, bamboo, animal, flower, sexual symbols, dream, etc. together, then we can create an interesting dialogue among them. Therefore, our interpretations of these symbols will be based not just only on thematic analysis, our experiences, our common knowledge, etc. This would be a fascinating research topic and therefore a more ambitious undertaking will have to come later.

\section{References}

Kinkley, J. C. (1987). The odyssey of Shen Congwen. Stanford, California: Stanford UP. Shen, C. W. (1981). The Border Town and other stories. (Gladys Yang, Trans.). Beijing: Panda Books. Tang, T. (Ed.). (1988). History of modern Chinese literature. Beijing: Foreign Language Press. Wah, W. Y. (1988). Essays on Chinese literature: A comparative approach. Singapore: Singapore UP. 